\title{
Musk deer Moschus cupreus persist in the eastern forests of Afghanistan
}

\author{
Stephane Ostrowsi, Haqiq Rahmani, Jan Mohammad Ali \\ Rita Ali and Peter ZAHLER
}

\begin{abstract}
Nuristan province, in north-east Afghanistan, holds a significant portion of the country's remaining forests, but because of the inaccessible terrain and the recent history of poor security little is known about the wildlife inhabiting these forests. We conducted transect surveys in central Nuristan and confirmed the presence of musk deer Moschus cupreus $>60$ years after the last documented observation of the species in Afghanistan. We found that, in summer, musk deer inhabit remote alpine scrub on scattered rock outcrops and in upper fringes of closed coniferous forests at c. $3,000-3,500 \mathrm{~m}$. They invariably use steep slopes $\left(\geq 20^{\circ}\right)$, which makes them difficult to approach. We built a data-driven geographical model, which predicted that suitable habitat for musk deer in Afghanistan extends over c. $1,300 \mathrm{~km}^{2}$ in the contiguous provinces of Nuristan (75.5\%), Kunar (14.4\%) and Laghman (10.1\%). Although relatively vast, the area of habitat potentially available to musk deer in Afghanistan appears to be highly fragmented. Despite indications of unsustainable hunting, this Endangered species persists in Afghanistan and targeted conservation programmes are required to protect it and its forest habitat.
\end{abstract}

Keywords Afghanistan, distribution range, Moschus cupreus, musk deer, Nuristan, suitable habitat

\section{Introduction}

$\mathrm{O}$ n 13 May 1948, in Afghanistan's Parun Valley in the remote eastern province of Kafiristan (now Nuristan), Knut Paludan (a member of the Third Danish Expedition to Central Asia, 1948-1949) observed '... an animal about the size of a roe deer, greyish like a roe in winter, but the hindquarters were not snow white; head small, narrow; antler or horn not seen' (Hassinger, 1973). The deer was identified as a musk deer Moschus sp. after a local elder was questioned and shown pictures of mammals from India. After seeing another deer similar to the first,

\footnotetext{
Stephane Ostrowski (Corresponding author) and Peter Zahler Wildlife Conservation Society, 2300 Southern Blvd, Bronx, 10460 NY, USA

E-mail sostrowski@wcs.org

HaQIQ RAHMani School of Geography, University of Leeds, Leeds, UK

Jan Mohammad Ali and Rita Ali Waygal, Nuristan, Afghanistan

Received 18 April 2014. Revision requested 4 June 2014.

Accepted 18 July 2014. First published online 22 October 2014.
}

Paludan concluded, '...the animals I have seen are musk deer'.

Since this first documented record of musk deer in Afghanistan, presumably of the Kashmir musk deer Moschus cupreus (Timmins \& Duckworth, 2008a), subsequent scientific expeditions have failed to confirm its presence, raising doubt about the species' persistence in the country. Naumann \& Nogge (1973) were told of an ungulate species that inhabited Kamu Valley in eastern Nuristan, which they identified as musk deer on the basis of responses of local hunters who were shown photographs of this species. Local people also reported the presence of musk deer in Nisheigram and Maktosho, in central Nuristan, to Petocz \& Larsson (1977), yet these authors neither observed the deer nor found signs of its presence. A biodiversity survey of central Nuristan during 2006-2008 using walked transects, camera traps and DNA identification of scats could not confirm the presence of musk deer (Stevens et al., 2011) even though the surveyed area was anticipated as a main stronghold of musk deer in Afghanistan (Habibi, 2003). However, musk deer are difficult to study because they are timid, solitary animals and remain hidden in dense, shrubby forest undergrowth during most of the day (Nowak, 1999). For this reason and because of the lack of security to investigate its preferred habitat in Afghanistan, the extent of musk deer distribution in Afghanistan has remained unknown.

The Kashmir musk deer is categorized as Endangered on the IUCN Red List, based on a suspected 50\% population decline across its range (Timmins \& Duckworth, 2008a), and it is believed to be rare in Afghanistan and threatened by over-exploitation (Habibi, 2003). Deforestation may pose a significant threat to the habitat of this forest-dwelling species, and results of a remote-sensing investigation (UNEP, 2003) suggested that Nuristan and the contiguous provinces of Kunar and Nangarhar lost $52 \%$ of their forests during 1973-2003. Given the precarious situation of the musk deer in Afghanistan it is important to reconfirm its presence there and estimate the extent of suitable habitat remaining. Here we report on environmental requirements and preferred habitat of the species as observed in central Nuristan and, considering habitat observations carried out in Pakistan and India on the Kashmir musk deer and on the closely related Himalayan musk deer Moschus leucogaster in Nepal (Timmins \& Duckworth, 2008b), propose a geographical model of suitable habitat for musk deer in Afghanistan. 


\section{Methods}

To evaluate the possible occurrence and range occupancy of musk deer in central Nuristan we carried out a wildlife mapping exercise during April-May 2008 based on community interviews across an area known to have potentially appropriate habitat (Stevens et al., 2011). To help identify locations for field surveys, local residents of 26 villages were asked to pinpoint on a map areas where musk deer occur at present and where they occurred 5 years ago. In case participants did not know how to read maps, field teams translated sites and regions mentioned to the appropriate areas on the map.

Using the information collected from this community mapping and from interviews with five self-identified hunters in the village of Waygal, a team conducted a survey in the Kashtoun mountain chain to the north-west of Waygal. During 21-30 June 2009 the team surveyed a remote area of c. $3 \mathrm{~km}^{2}$, on foot, focusing on early morning and late evening to increase opportunities to encounter musk deer. Eight transects were surveyed over a total of c. 39 hours, with surveyors recording any evidence of the presence of the species (e.g. sightings, faeces, latrines, bedding sites, tracks), and location, elevation and habitat type (closed coniferous forest, mixed coniferous/deciduous forest, rock outcrop with meadows, or rangeland). The cliffs in the area made it inaccessible to livestock but markhor Capra falconeri may have been present, and therefore only musk deer sightings, characteristic latrines, and bedding sites with recognizable hairs were included as evidence of presence. Hair fibres were examined using microscopy and compared with reference hairs of Kashmir musk deer, markhor and livestock, and published photographic keys (Anwar et al., 2012). Guard hairs of the outer coat of musk deer present a characteristic isodiametric cuticular scale pattern, a wineglass-shaped root, and a midshaft diameter more than double that of any other ungulate hair in the region. As a result of the deteriorating security conditions in the east of Afghanistan since early 2010 the results of this survey could not be retrieved from the research team until late 2012, and hair samples were analysed in 2013.

We constructed a geographical model of suitable habitat for musk deer in Afghanistan based on a method described by Kanderian et al. (2009), using habitat macrofeatures described by satellite imagery, aerial photography and a geographical information system. The two main variables used to describe the habitat were ecoregion and land cover type; elevation, slope and proximity to human settlements were used as refining variables. To determine the ecological requirements of musk deer and correlate them with habitat variables we used information derived from our interview and survey results and from a literature survey (Green, 1985,1986; Kattel \& Alldredge, 1991; Qureshi et al., 2004; Rajchal, 2006; Qamar et al., 2008). We identified suitable ecoregions for musk deer in Afghanistan by extrapolating ecoregional information for musk deer in Pakistan and northern India, and using the WWF WildFinder database (WWF, 2012), which lists the ecoregions (Olson et al., 2001) and species found within them. We linked our survey results and relevant habitat descriptions from the literature to Afghanistan's 21 land cover types, mapped by the Food and Agriculture Organization (FAO, 2014) during 19901993 by photointerpretation of available Landsat Thematic Mapper satellite data at $30-\mathrm{m}$ resolution. The elevation and slope data gathered from the field were used to refine the species' range coverage. Elevation and slope data were extracted from Shuttle Radar Topography Mission digital elevation models at 90-m spatial resolution across Afghanistan (CGIAR-CSI, 2008). Information on human settlements was sourced from digitized settlement maps made during 1967-1988 (AIMS, 2014).

We determined that all suitable habitat for musk deer in Afghanistan lies within three ecoregions: Northwestern Himalayan alpine shrub and meadows, Hindu Kush Alpine meadows, and East Afghan montane conifer forests. Within these ecoregions we selected three types of land cover as inclusive of all potential habitats for musk deer: closed forest, open forest (possibly only used in winter when high alpine pastures and subalpine forest become unsuitable because of heavy snowfall), and high-elevation rock outcrops with alpine meadows. We included elevations of $2,000-3,600 \mathrm{~m}$ and slopes $\geqslant 20^{\circ}$, and excluded areas within $1 \mathrm{~km}$ of human settlements as unfavourable to musk deer. Habitat suitability modelling was carried out at a $90 \times 90$ $\mathrm{m}$ ground resolution using the ModelBuilder tool in ArcGIS v. 10.0 (ESRI, Redlands, USA). ModelBuilder is used to develop new geoprocessing workflows and customize existing models, using a step-by-step (on-screen) approach (Malczewski, 2004).

\section{Results}

For the mapping exercise c. 10 adult males were interviewed in each village, with 249 interviews in total. Only limited information could be inferred from these interviews, given the small sample size ( $<3 \%$ of the population) and the questionable reliability of the participants' knowledge of musk deer. Only $14 \%$ of responses affirmed the presence of musk deer in central Nuristan, supporting the possibility that the species is rare or particularly elusive. Analysis of responses according to a remoteness gradient showed that the species was reported significantly more frequently by respondents living in remote northern villages $(30.3 \%, \mathrm{n}=66$ respondents) than those in less remote central $(5.9 \%, \mathrm{n}=84)$ and southern $(10.1 \%, \mathrm{n}=99)$ villages $\left(\chi^{2}=20.1, \mathrm{P}<0.001\right)$. The distribution of the species is reportedly limited to the upper reaches $(>2,000 \mathrm{~m})$ of the Kashtoun mountain chain, north-east of Nisheegram and Wama villages, steep and remote areas near Kantewa and Pashki villages in the 


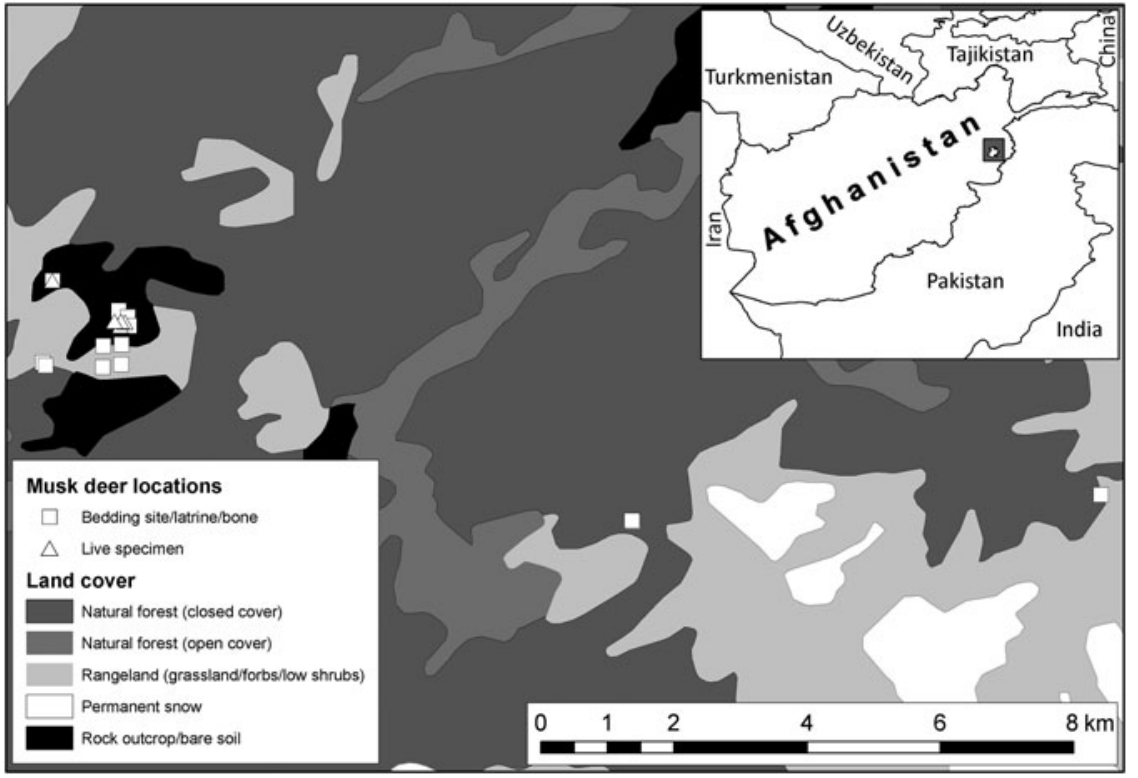

FIg. 1 Locations where evidence of musk deer Moschus cupreus was recorded in the Kashtoun mountains, in Nuristan province. The shaded square on the inset shows the location of Nuristan province in Afghanistan.

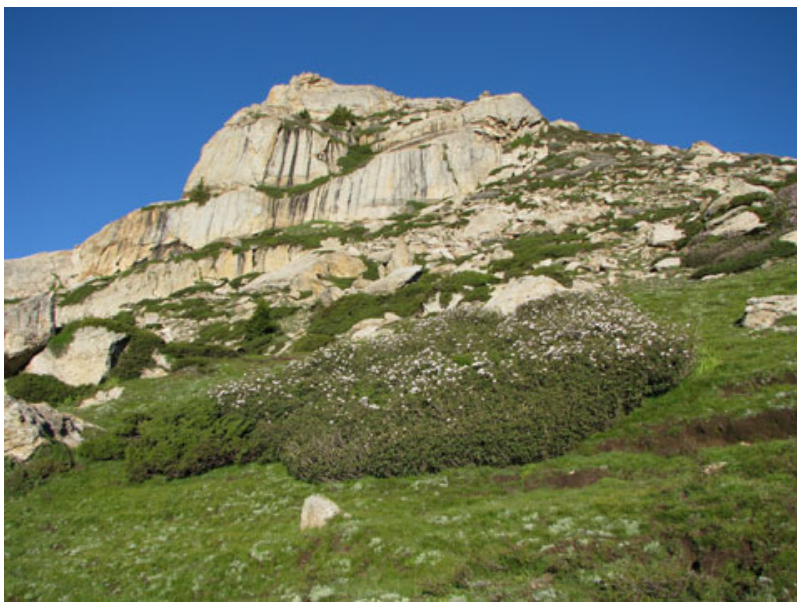

Plate 1 Summer habitat of musk deer Moschus cupreus in Nuristan, with rock outcrops, alpine meadows, scattered currant bushes, dense rhododendron, and juniper scrubs on steep slopes $\left(\geq 20^{\circ}\right)$, above the tree line $(>3000 \mathrm{~m})$.

north, and both sides of the border of Kunar province in the south-east. Interview responses suggest that 5 years before the survey musk deer had a wider distribution in the south of the region, at lower elevations. According to hunters in Waygal, musk deer perform seasonal altitudinal movements; in winter, in response to heavy snowfall, they descend from preferred pastures above the tree line to coniferous forests.

The survey team recorded five sightings of 1-2 musk deer, including a solitary male in the same area on three occasions, one female with a juvenile, and one solitary female (which may have been the same individual without her young). All sightings were in steep $\left(>20-30^{\circ}\right)$ rock outcrop habitat interspersed with alpine meadows and scattered, dense 0.5-1 $\mathrm{m}$ high bushes of Juniperus squamata,
Rhododendron spp. and Ribes spp. at altitudes of 3,1783,304 $\mathrm{m}$ (Plate 1). The team also recorded two bedding sites at the upper edge of coniferous forest, two latrines with recognizable hairs in rock outcrop areas, and a mandible bone with hairs, to the east of the study site, all at $\geqslant 3,170 \mathrm{~m}$ (Fig. 1). All animals were seen active during early morning (04.30-06.30) and were not observed during the rest of the day except for the solitary male observed on one occasion in the evening (16.50). Few behavioural observations could be made. On four occasions deer were observed standing still, obviously aware of human presence, and only on one occasion the solitary male was seen feeding on forbs in a meadow. The team also found evidence of browsing on new shoots of conifer branches at the edge of the tree line. The musk deer were discrete, cryptic and difficult to spot.

On 4 July 2009 in a household near Waygal the team photographed a dead adult female musk deer that had been hunted the previous day in the Kashtoun mountain range (Plate 2). This was the first time the species was photographed in Afghanistan. The hairs collected from this specimen were used as a standard for manual microscopy comparisons.

Our geographical model predicts that suitable habitat for musk deer in Afghanistan covers c. $1,300 \mathrm{~km}^{2}$ in the contiguous provinces of Nuristan (75.5\%), Kunar (14.4\%) and Laghman (10.1\%). The largest patch of continuous suitable habitat is $522 \mathrm{~km}^{2}$, or almost $40 \%$ of the total area of suitable habitat, and overlaps western Nuristan, east Laghman and west Kunar (Fig. 2). In terms of ecoregions, the Hindu Kush alpine meadow ecoregion is the most represented (43.5\%), followed by East Afghan montane conifer forests (31\%) and Northwestern Himalayan alpine shrub and meadows (25.5\%). The land cover within the predicted habitat 


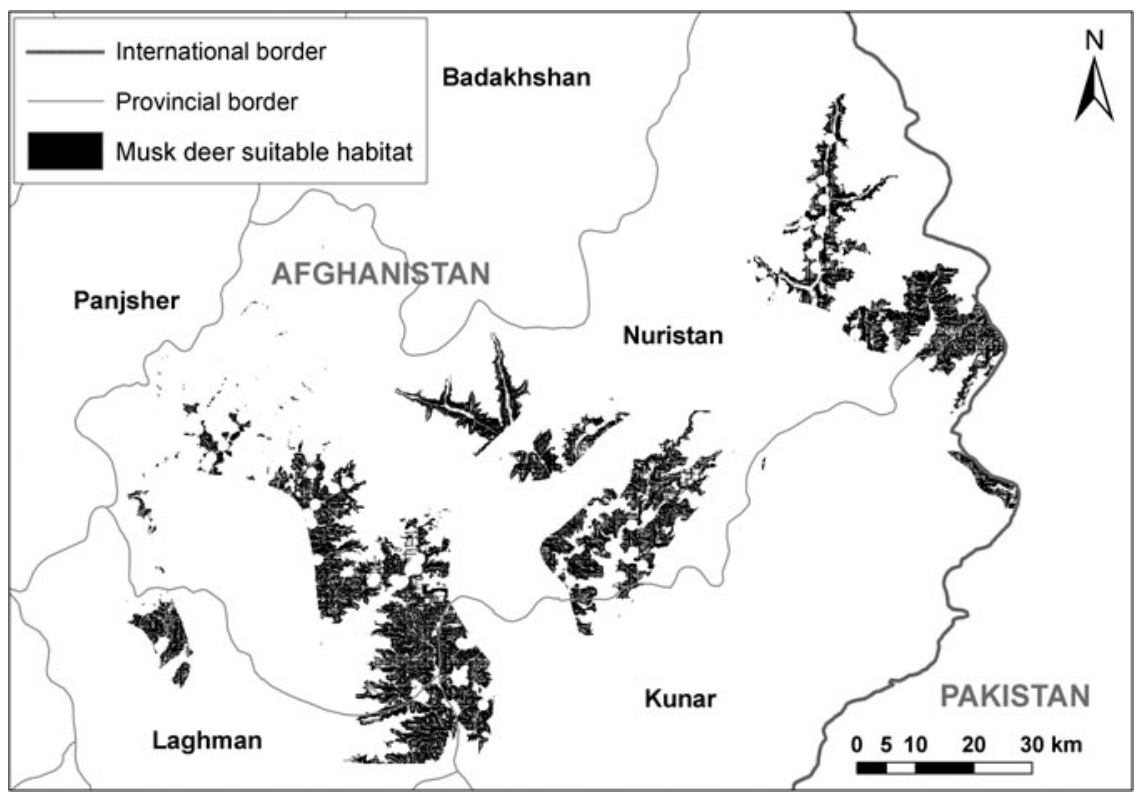

FIG. 2 Locations of suitable habitat for musk deer in Afghanistan, based on environmental requirements and preferred habitat of the species as observed in central Nuristan, Pakistan and India, and of the closely related Himalayan musk deer Moschus leucogaster in Nepal.

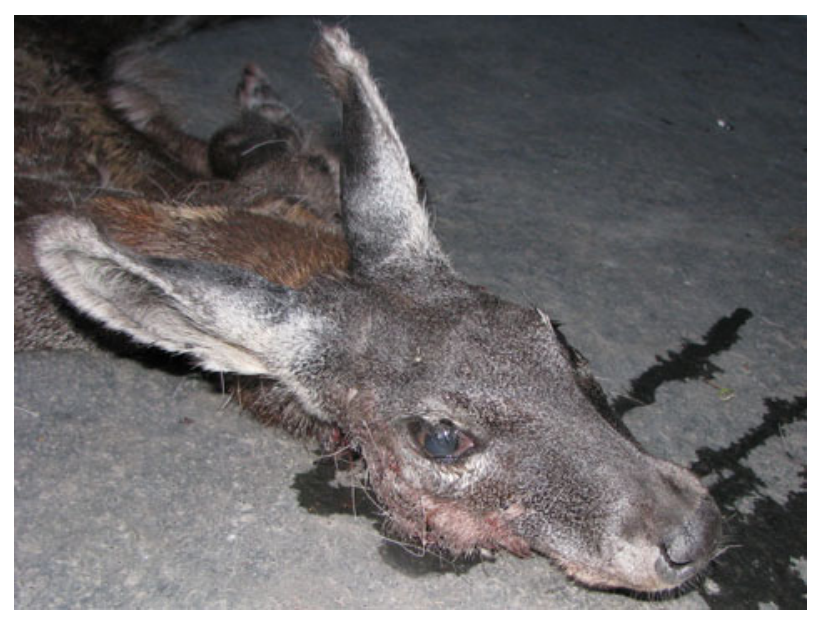

Plate 2 Carcass of an adult female musk deer hunted in the Kashtoun mountain range (Fig. 1) on 3 July 2009.

model is composed of $84.1 \%$ closed forest, $11.4 \%$ open forest and $4.5 \%$ rock outcrop. All fragments of suitable habitats have the three types of land cover except the easternmost areas along the international border with Pakistan, which have no rock outcrop cover.

\section{Discussion}

This wildlife survey in the eastern forests of Afghanistan after 3 decades of war indicates that the musk deer still persists there despite unregulated hunting, extensive deforestation, habitat degradation, and the absence of rule of law. To our knowledge our study provides the first documented record of the musk deer in Afghanistan since 1948 (Hassinger, 1973), the first photograph of a wild specimen from Afghanistan, and the westernmost location of musk deer in Asia.

In central Nuristan we found that, in summer, musk deer inhabit remote alpine scrub on scattered rock outcrops, and the upper fringes of closed coniferous forests at c. 3,000$3,500 \mathrm{~m}$. They invariably use steep slopes $\left(\geq 20^{\circ}\right)$, which makes them difficult to approach and presumably difficult to hunt. According to local inhabitants musk deer spend the winter season in the undergrowth of mixed coniferous forests (possibly as low as 2,000-2,500 $\mathrm{m}$ ), where tree branches provide them with food as well as shelter from heavy snowfall. The altitudinal distribution of our musk deer sightings differs from that proposed previously $(1,500-3,000 \mathrm{~m}$; Habibi, 1977) but overlaps with results of surveys carried out more recently in Azad Jammu and Kashmir, Pakistan (2,270-3,860 m; Qureshi et al., 2004). The pattern of seasonal movements across the habitat appears to be similar to that observed in Neelum Valley, Pakistan (Qureshi et al., 2004).

Our landscape-scale habitat suitability model provides an estimate of the potential range of the musk deer in Afghanistan. Although relatively vast, the area of habitat potentially available to musk deer in Afghanistan is discontinuous, fragmented by steep valleys with human habitation and high mountain ranges, with areas of suitable habitat sometimes separated by $>20 \mathrm{~km}$. The preferred summer habitat, on rock outcrops, covers only $60 \mathrm{~km}^{2}$, which suggests that the population of musk deer in Afghanistan is small. Increasing the upper threshold for altitude in the geographical model to $4,200 \mathrm{~m}$, to match highest altitude records from Chitral, Pakistan (Roberts, 2005), increased the area of suitable habitat by only $80 \mathrm{~km}^{2}$, of which $<60 \%$ had a geographical continuity with the rest of the predicted suitable habitat. Similarly, decreasing the minimum slope to $15^{\circ}$ added only $189 \mathrm{~km}^{2}$ of favourable habitat. Both 
modifications combined resulted in a relatively modest increase $(<20 \%)$ in the predicted extent of musk deer habitat in Afghanistan.

The accuracy of the land cover information used in our model may be questionable, given the significant deforestation that has taken place in the eastern forest complex of Afghanistan (UNEP, 2003). However, habitat information for locations where musk deer were observed matched the land cover information accurately (Fig. 1). More importantly, and contrary to the claims of UNEP (2003), a tentative assessment of forest loss and deforestation trends undertaken during 2007-2008 by the Wildlife Conservation Society, using recent satellite imagery, did not find evidence of large-scale deforestation of the conifer forests or signs of imminent ecological calamity across eastern forests (Delattre \& Rahmani, 2009). These findings were confirmed by ground assessment and overflight transect surveys carried out in 2010 in Kunar, Laghman, Nuristan and Nangarhar provinces by the Natural Resources Counterinsurgency Cell of the U.S. Army (Bader et al., 2010). These surveys did not find significant degradation of the upper-elevation coniferous forests used by musk deer, whereas the lower-elevation oak forest $(<2,000 \mathrm{~m})$ was reported to have suffered significant deforestation locally (Bader et al., 2010). Although these results are encouraging for the conservation of musk deer, more subtle forest degradation, as opposed to blanket removal of all standing trees, may be occurring in the upper coniferous forest zone and could have a significant impact on the fragmented habitat of the musk deer.

Unregulated hunting may be the most serious threat to musk deer in Afghanistan, as has been documented for Himalayan and Kashmir musk deer (Green, 1987; Khan et al., 2006; Mishra et al., 2006). During summer these species stay in relatively inaccessible high mountain areas and are hunted opportunistically when encountered. However, when heavy snowfall in winter drives the animals to more accessible, lower-elevation areas they become vulnerable to hunters, who come to central Nuristan from as far as Kunar province to hunt (J.M. Ali, pers. comm.). Besides being hunted for meat, which is considered a local delicacy, the musk deer is primarily hunted for its musk-secreting preputial gland, which is valued for its fixative and scent properties. According to local people, hunting for musk began in the area in the early 1970 s and has increased substantially since then. Petocz \& Larsson (1977) were informed that Moschus glands were sold in the Jalalabad Valley for USD 20-30. Nowadays traders reportedly pay up to USD 200-250 per gland (J.M. Ali, pers. comm.).

The future of the forest habitat of Afghanistan's musk deer depends on the extent of logging activities in eastern forests, which are currently controlled illegally by smuggling networks involving corrupt officials, insurgents and criminal elements operating across the border with Pakistan
(Bader et al., 2010). Although the deteriorating security conditions in Nuristan did not allow NGOs to remain in Nuristan after 2011, the Wildlife Conservation Society maintains contact with the local people it has trained and will pursue funding to continue ecosystem research and protection in Nuristan when the situation improves.

\section{Acknowledgements}

This study was made possible by the generous support of the American people through the United States Agency for International Development (USAID). The contents of the article are the responsibility of the Wildlife Conservation Society (WCS) and do not necessarily reflect the views of USAID or the United States Government. Surveys would not have been possible without the support of successive WCS country directors during 2006-2009: Alex Dehgan, Peter Smallwood and Dave Lawson. We thank the first WCS team in Nuristan for the questionnaire survey results. We thank Rohullah Sanger for editing the figures.

\section{References}

Aims (Afghanistan Information Management Services) (2014) Http://www.aims.org.af [accessed 18 August 2014]. Anwar, M.B., Nadeem, M.S., Beg, M.A., Kayani, A.R. \& Munammad, G. (2012) A photographic key for the identification of mammalian hairs of prey species in snow leopard (Panthera uncia) habitats of Gilgit-Baltistan Province of Pakistan. Pakistan Journal of Zoology, 44, 737-743.

Bader, H.R., Douglas, C., Fairchild, J., Kaczmarek, D. \& Hanna, C. (2010) The Afghanistan Timber Trade: An Evaluation of the Interaction Between the Insurgency, GIRoA and Criminality in the Task Force Bastogne Area of Operations (Nuristan, Kunar, Laghman, and Nangarhar). Unpublished report. Natural Resources Counterinsurgency Cell, U.S. Army, USA.

CGIAR-CSI (CGIAR Consortium For SpATIAL INFormation) (2008) SRTM 9om Digital Elevation Data. Http://srtm.csi.cgiar.org [accessed 18 August 2014].

Delattre, E. \& Rahmani, H. (2009) A Preliminary Assessment of Forest Cover and Change in the Eastern Forest Complex of Afghanistan. Unpublished report. Wildlife Conservation Society, New York, USA.

FAO (Food and Agriculture Organization) (2014) Afghanistan. Http://www.fao.org/world/Afghanistan [accessed 18 August 2014].

Green, M.J.B. (1985) Aspects of the ecology of the Himalyan musk deer. $\mathrm{PhD}$ thesis. University of Cambridge, Cambridge, UK.

Green, M.J.B. (1986) The distribution, status and conservation of the Himalayan musk deer Moschus chrysogaster. Biological Conservation, 35, 347-375.

Green, M.J.B. (1987) Scent-marking in the Himalayan musk deer (Moschus chrysogaster). Journal of Zoology, 1, 721-737.

Hавіві, K. (1977) The Mammals of Afghanistan: Their Distribution and Status. Unpublished report. UNDP/FAO Department of Forest and Range, Kabul, Afghanistan.

Hавіві, K. (2003) Mammals of Afghanistan. Zoo Outreach Organization, Coimbatore, India. 
Hassinger, J. (1973) A survey of the mammals of Afghanistan, resulting from the 1965 Street Expedition (excluding bats). Fieldiana Zoology, 60, 1-195.

Kanderian, N., Shank, C., Johnson, M., Rahmani, H. \& Hatch, C. (2009) Identifying Priority Zones for a Protected Area Network in Afghanistan. CBD/POWPA Technical Report (unpublished). National Environmental Protection Agency, Kabul, Afghanistan.

Kattel, B. \& Alldredge, A. (1991) Capturing and handling of the Himalayan musk deer. Wildlife Society Bulletin, 19, 397-399.

Khan, A.A., Qureshi, B. \& Awan, M. (2006) Impact of musk trade on the decline in Himalayan musk deer Moschus chrysogaster population in Neelum Valley, Pakistan. Current Science, 91, 696-699.

MALCZEWSKI, J. (2004) GIS-based land-use suitability analysis: a critical overview. Progress in Planning, 62, 3-65.

Mishra, C., Madhusudan, M.D. \& Datta, A. (2006) Mammals of the high altitudes of western Arunachal Pradesh, eastern Himalaya: an assessment of threats and conservation needs. Oryx, 40, 29-35.

Naumann, C. \& Nogge, G. (1973) Die Grossäuger Afghanistans. Zeitschrift des Kölner Zoo, 3, 79-93.

NoWAK, R. (1999) Walker's Mammals of the World, 6th edition, volume 2. Johns Hopkins University Press, Baltimore, USA.

Olson, D.M., Dinerstein, E., Wikramanayake, E.D., Burgess, N.D., Powell, G.V.N., Underwood, E.C. et al. (2001) Terrestrial ecoregions of the world: a new map of life on earth. BioScience, 51, 933-938.

Petocz, R. \& Larsson, J. (1977) Ecological Reconnaissance of Western Nuristan with Recommendations for Management. FO:DP/AFG/74/ o16 Field Document No. 9 (unpublished report). Food and Agriculture Organization of the United Nations, Kabul, Afghanistan

Qamar, Q.Z., Anwar, M. \& Minhas, R.A. (2008) Distribution and population status of Himalayan musk deer (Moschus chrysogaster) in the Machiara National Park, AJ\&K. Pakistan Journal of Zoology, 40, 159-163.

Qureshi, B., Awan, M.S., Khan, A.A., D ar, N.I. \& Dar, M.E. (2004) Distribution of Himalayan musk deer (Moschus chrysogaster) in
Neelum Valley, District Muzaffarabad, Azad Jammu and Kashmir. Journal of Biological Sciences, 4, 258-261.

Rajchal, R. (2006) Population Status, Distribution, Management, Threats and Mitigation Measures of Himalayan Musk Deer (Moschus chrysogaster) in Sagarmatha National Park. Unpublished report. Institute of Forestry, Pokhara, Nepal.

Roberts, T.J. (2005) Field Guide to the Large and Medium-Sized Mammals of Pakistan. Oxford University Press, Oxford, UK.

Stevens, K., Dehgan, A., Karlstetter, M., Rawan, F., Tawhid, M.I., OstrowsKi, S. et al. (2011) Large mammals surviving conflicts in the eastern forests of Afghanistan. Oryx, 45, 265-271.

Timmins, R.J. \& Duckworth, J.W. (2008a) Moschus cupreus. In IUCN Red List of Threatened Species v.2012.2. Http://www. iucnredlist.org [accessed 22 December 2013].

Timmins, R.J. \& Duckworth, J.W. (2008b) Moschus leucogaster. In IUCN Red List of Threatened Species v.2012.2. Http://www. iucnredlist.org [accessed 22 December 2013].

UNEP (United Nations Environment Programme) (2003) Afghanistan: Post-Conflict Environmental Assessment. Unpublished report. United Nations Environment Programme, Nairobi, Kenya. WWF (2012) Wildfinder Database. Http://www.worldwildlife.org/ publications/wildfinder-database [accessed 18 August 2014].

\section{Biographical sketches}

Stephane Ostrowsin provides technical support in eco-health, science and monitoring to conservation projects in Afghanistan, China, Iran, Mongolia, Pakistan, Russia and Tajikistan. Ha qiQ RAhmani was the Afghanistan geographical information system manager for the Wildlife Conservation Society during 2006-2014 and is now pursuing MSc studies in geographical information systems. JAN Moнammad Ali and Rita Ali improve the livelihoods of their community in central Nuristan through education and enhanced management of natural resources. Peter Zahler designs and supervises conservation programmes across Asia. 